\title{
IS ANOTHER COSMOPOLITICS POSSIBLE?
}

\author{
MARIO BLASER \\ Memorial University of Newfoundland \\ (D) http:/ / orcid.org/0000-0001-5613-6669
}

Cosmopolitics is now the common situation for all collectives. There is no common world, and yet it has to be composed, nonetheless.

- Bruno Latour

On January 28, 2013, the government of Newfoundland and Labrador announced a five-year hunting ban on caribou. The ban was imposed after several surveys showed that the population of the George River Herd had been dropping precipitously, from eight hundred thousand individuals in 1990 to only twentyseven thousand in 2012. While uncertain about the causes, the provincial government understood that a continued caribou harvest was not sustainable, even for the Innu and Inuit indigenous communities that live in Labrador. The day after the announcement, Prote Poker, the Innu Nation grand chief, said that the ban was unjustifiable; that Innu elders did not agree with it because it was a threat to their way of life; and that the communities would continue to hunt as they always had (CBC News 2013). Among other concerns, the Innu refusal to accept the ban was based on the insistence of knowledgeable hunters and elders who saw the decline in population as a symptom of the deteriorating relationship between the Innu and Kanipinikassikueu, the master of atîku (the word Innu use to refer to what Euro-Canadians call caribou). ${ }^{1}$ The extent to which established protocols for hunting are followed — such as the treatment of bones and the 
sharing of meat, among other prescriptions - determines the health of that relationship and the willingness of Kanipinikassikueu to keep giving animals to, and generally bless, the Innu. Hunters and elders had been complaining for several years by then that younger generations of Innu were not following these protocols, calling on the young people to recommit to them. In this context, for hunters and elders, the hunting ban would make it impossible to repair the relationship with atîku and its spirit master. In short, while for the wildlife managers in the provincial government hunting could mean the disappearance of the caribou, for the Innu hunters and elders, being prevented from hunting according to protocol almost assuredly would mean the disappearance of atîku. ${ }^{2}$

Thinking about possible ways to grapple with this seemingly intractable conflict calls to mind the concept of cosmopolitics. This concept, first proposed by Isabelle Stengers (1997), differs from Kantian cosmopolitanism, according to which a cosmopolitan is one who rejects parochial allegiances and embraces the common world (the cosmos) as the grounding to work out differences among humans. In this conception the cosmos is transcendent and requires no discussion. What is debated (and has to be resolved) are the different views that, given their allegiance to their cultures and traditions, humans have about that cosmos. Returning to our example, a cosmopolitan call to resolve the disagreement between the Innu and the provincial government would appeal to the parties to abandon their respective parochial perspectives and focus instead on what is common to both: the "thing" they worry about, a thing that one calls caribou and the other atîku. In a discussion with Ulrich Beck, and mobilizing Stengers's notion of cosmopolitics, Bruno Latour (2004a) points out that humans do not go into conflicts with their perspectives on things; they go into them along with the nonhuman things that make them act. In this sense, caribou and atîku would not refer to different cultural perspectives on the same "thing," but to altogether different (albeit not unrelated) things. Thus, Stengers and Latour locate the problem with cosmopolitanism in its assumption of an already unified cosmos, a single world (the common "thing"), when we actually inhabit a pluriverse. Such a pluriverse requires a cosmopolitics.

Stengers $(2005,995)$ recounts that she came up with the term cosmopolitics when she found herself at risk of turning a type of practice into a universal neutral key. On her account, "the so-called modern sciences appeared to be a way of answering the political question par excellence: who can talk of what, be the spokesperson of what, represent what?" The risk, she says, was forgetting that the category of politics with which she was working derived from a particular 
tradition, and thus, she decided to articulate it with the term cosmos. Far from referring to a "particular cosmos, or world, as a particular tradition may conceive it," in her usage "cosmos refers to the unknown constituted by these multiple, divergent worlds, and to the articulations of which they could eventually be capable" (Stengers 2005, 995; my emphasis). The reference to the possible articulations that divergent worlds might develop connects cosmos back to politics in two ways: 1) it interrupts its universality (politics is our signature; we do not know the procedures that other worlds have devised to constitute themselves as common), and 2) it enrolls politics to explore the possibility of those divergent worlds articulating with each other to become a common world. ${ }^{3}$ Latour (2004a, 454) captures succinctly what Stengers's invention of the word cosmopolitics achieves:

The presence of cosmos in cosmopolitics resists the tendency of politics to mean the give-and-take in an exclusive human club. The presence of politics in cosmopolitics resists the tendency of cosmos to mean a finite list of entities that must be taken into account. Cosmos protects against the premature closure of politics, and politics against the premature closure of cosmos.

Conceived thus, cosmopolitics speaks to the intersection of two topics that have enlivened anthropological debates lately: on the one hand, under the labels of multispecies ethnography (Kirksey and Helmreich 2010) and new materialism (Coole and Frost 2010), the revaluation of agency as an attribute distributed across heterogeneous assemblages of humans and nonhumans; and, on the other hand, under the label of the ontological turn (Holbraad, Pedersen, and Viveiros de Castro 2014; Kohn 2015), the revaluation of radical alterity as an index of multiple ontologies or worlds rather than cultures. Each of these interventions coincides with a politics and a cosmos that are expanded by cosmopolitics. Yet they still run the risk of becoming closed if they are not connected to one another. For instance, as Christopher Gad, Casper Bruun Jensen, and Brit Winthereik (2015) argue, some scholars enrolled in the ontological turn give too much weight to the concepts of human informants, while paying little attention to the role of nonhumans. ${ }^{4}$ Conversely, Danielle DiNovelli-Lang (2013) and I (Blaser 2014) have pointed out that multispecies ethnography and new materialism tend to rely heavily on the natural sciences as spokespersons for the nonhumans admitted into politics, and thus they continue to delineate a cosmos with a limited number of legitimate entities. ${ }^{5}$ The kind of conflict I described above short-circuits any premature closure of politics and cosmos, even if these are expanded, and thus forces us to retain the two components of cosmopolitics in tension. 
But beyond academic debates, by keeping open the question of who and what might compose the common world, cosmopolitics offers a way to grasp these kinds conflicts while avoiding the pitfalls of what I call the problem of reasonable politics. I will expand on this below; for now it will suffice to indicate that the problem with reasonable politics lies in defining in advance what kinds of differences are at stake in such conflicts (as cosmopolitanism does), thereby reinforcing a state of affairs whereby some concerns (rendered as perspectives) can be sidelined - like the claim that Innu are given atîku by a spirit masterbecause they are deemed unrealistic and, therefore, unreasonable or irrelevant.

Figuring the common world as its possible result, rather than as a starting point, cosmopolitics disrupts the quick recourse to rule out concerns on the basis of their deemed lack of reality. Indeed, the primary purpose of the cosmopolitical proposal was to "slow down reasoning and create an opportunity to arouse a slightly different awareness of the problems and situations mobilizing us" (Stengers 2005, 994). And yet, as my epigraph from Latour indicates, the common world must be composed. Thus, although Latour and Stengers denote distinct senses of urgency, for each of them cosmopolitics remains oriented to the composition of the common world, even if they insist on the lack of guarantees for such a project. In this article I argue that such an orientation limits the capacity of cosmopolitics to address the kinds of conflicts I described above. To substantiate my argument, I will submit cosmopolitics to a pragmatic test by diffractively reading it (Barad 2007, 200) through ethnographic materials. My concern is not primarily with endorsing or rejecting the concept of cosmopolitics, but rather with seeing what elements of it are useful to tackle this conflict as a politico-conceptual problem and where the ethnography suggests a need to expand the concept. I will first present a general outline of the problem of reasonable politics, highlighting those aspects for which cosmopolitics, and the material semiotics in which it is grounded, seem to offer some handles. I then move on to the test proper, exploring the extent to which cosmopolitics provides a fruitful concept for the conflict that concerns me. Finally, following the contours of what cosmopolitics seems unable to adequately address in my ethnographic materials, I advance a series of suggestions for another cosmopolitics.

\section{THE PROBLEM OF REASONABLE POLITICS}

What I call the problem of reasonable politics resembles a typical ethnographic puzzle, that is, how to gauge utterances that appear to the researcher as manifestly counterfactual. The classic example would be the Nuer declaration that 
twins are birds when the researcher knows that they are human siblings. Usually the resolution of the puzzle involves explaining how and why the Nuer would think that twin human siblings are birds. Martin Holbraad has pointed out that such a resolution reflects the analyst's prior assumption that different cultural representations of twins are at stake (Carrithers et al. 2010). Smuggled into this assumption is the implicit claim that the analyst gets it right (i.e., twins are actually human siblings), while the Nuer get it wrong (i.e., they produce cultural representations of twin human siblings that are a bit off the mark and require explanation). The problem of reasonable politics becomes most visible when, rather than in the realm of ethnographic encounters, the puzzle of counterfactual utterances occurs in the realm of conflicts where matters of life and death are at stake, or when certain kinds of lives are deemed possible while others are not. Conflicts surrounding entities that states and corporations treat as resources and that others take as nonhuman or suprahuman persons with whom they sustain various social relations - as is the case of the Innu with atîku and its spirit master-are thus exceedingly apt to make evident the problem of reasonable politics.

Elsewhere, and through ethnographically inspired discussion, I (as well as other colleagues) have addressed the conceptual problems these kinds of conflicts pose. Marisol de la Cadena (2010, 342), for example, has argued that these conflicts bring to the fore a conceptual challenge to politics as usual. The presence of nonhuman persons, in her case earth-beings, in politics disavows "the separation between 'Nature' and 'Humanity,' on which the political theory our world abides by was historically funded." In turn, I have argued that by deploying the concept of culture in trying to empower those who foreground entities' status as nonhuman persons, we find ourselves at an impasse (Blaser 2013a). By presenting nonhuman persons as culture, we end up treating these conflicts as epistemological, that is, as between perspectives on the world. (One cultural perspective sees persons, while the other sees resources.) This move reinstates and reinforces the ontological assumptions implicit in the modern constitution (i.e., the nature/ culture divide and its cascading binaries). The alternative, I have argued, is to treat these kinds of conflicts as ontological conflicts rather than cultural differences (Blaser 2009, 2013b).

The core of the problem here is that the modernist assumption of one world with multiple perspectives on it is constitutive of what I call reasonable politics and its operations. In a nutshell, reasonable politics operates on the basis of turning differences into perspectives on the world. Differences made into perspectives are amenable to be ranked according to putative degrees of equivalence between 
perspectival representations of the world and the factual world itself. This ordering, in turn, makes it possible to deem some perspectives irrelevant, erroneous, or dangerous, and thus dismissible or, worse, destroyable (see Povinelli 2001, 2002). The process of attributing factuality is extremely contested. Yet the power of reasonable politics rests precisely in its capacity to set the terms of contestation (or disagreement) as a matter of perspectives competing for factuality. This is particularly problematic for those who do not adhere to the epistemology derived from the ontological assumption of one factual world; because they are not engaged in a contest over factuality on the terms set by reasonable politics, their claims are automatically disqualified as being unreasonable or unrealistic.

Precisely because of the primacy of an epistemology predicated on the notion that knowledge is a relation between a real world out there and representations of it, Universal Science plays the primary role of arbiter in reasonable politics, especially in the exercise of ranking the putative factuality of different perspectives. ${ }^{6}$ Universal Science is an always shifting and situated material-semiotic assemblage in which the state, law, and knowledge practices claiming scientific status are entangled. Such a configuration makes plausible, mobilizes, and protects an implicit equivalence between technological prowess and apprehending reality as it is. In very simplistic terms: we know that science knows better because we can send a man to the moon, and if you want to prove otherwise you will have to enroll the services of a natural or social scientist! Universal Science is of course not the only criteria mobilized to rank competing factualities, but it does tend to be the primary one.

Besides screening out putatively unreasonable or unrealistic concerns, reasonable politics poses another problem for the analyst who wants to escape its confines, namely, how to account for the differences at stake in conflicts like those above if one wants those differences to make a difference in the way they are accounted for. The problem emerges from a particular notion of politics that takes some inspiration from Jacques Rancière. Rancière $(2011,4)$ has argued that disagreement is both foundational to politics and holds the possibility to generate a "re-partitioning [of] the political from the non-political." Building on this, I treat politics as a placeholder for: 1) differences that, while being potentially the ground for disagreement, are yet to be defined, and 2) the various possible ways in which these differences might (or might be made to) relate to each other. Reasonable politics (or politics as usual) takes for granted its universal applicability and, more important, assumes that it has exhausted categories of difference (such as culture, 
class, gender, race, sexuality, and so on). Moving away from this position which presupposes that disagreements are easily recognized, in my politics as placeholder, the very nature (and existence) of differences qua differences can be what is at stake, and constitutive of, the disagreement. For example, some parties and analysts might maintain that the conflict over caribou is a class conflict over the control of a resource. In this case the difference/disagreement is about who owns or controls the resource. Perhaps that is the case, and the conflict will play out in relation to such disagreement. But maybe there are other parties and analysts that view the conflict as a cultural conflict involving competing knowledges. In that case the difference/disagreement is premised on who got the problem right, and the conflict itself will unfold differently. Given that conflicts unfold differently depending on the kind of disagreement at stake, defining the very nature of the disagreement - is it about control of resources or is it about competing knowledges? - can become the mediating principle at work in the conflict. Yet there might be another twist. Let's say that yet another party claims (as we will see later) that the conflict involves protecting the web of relations that sustain the life of the Innu, while other parties, in turn, entirely reject the idea that such a thing could be at issue; they care about the life of the Innu as well. In this case, it is the very existence of the disagreement about which the parties differ and disagree that is operative. Of course, all these disagreements (and others still to reveal themselves) might be operating simultaneously. For this reason, it is important, in principle, to remain as agnostic as possible about what kinds of differences might constitute the political in a given situation. ${ }^{7}$ In part, this holds because the task of the analyst cannot be disentangled from how the disagreement unfolds. Whether and how the differences at stake make a difference, at a minimum, implies that such differences be articulated and made visible, not the least by the analysts themselves. As I have pointed out, an analysis in terms of representations or perspectives on a factual world does precisely the contrary, as it stipulates from the beginning what kinds of differences are at stake and, in so doing, ends up playing into the hands of reasonable politics and its exclusionary operations.

The material-semiotic versions of science and technology studies on which the concept of cosmopolitics is empirically grounded offer a way to address the exclusionary drive of reasonable politics and the analytical need to remain agnostic to the differences at stake in politics. Material semiotics postulates factuality as an always emergent enactment of heterogeneous assemblages; only a posteriori might they be purified as pertaining either to facts or to representations (Haraway 
1988; Latour 1999; Law 2009). This formulation has been greatly informed by what transpires in the sites where scholars study scientific practices. These are locations of construction and of ontological uncertainty; they are sites defined by concerns or issues that are contoured by the presence of actants that, if they are able to articulate successfully, might become a matter of fact. To put it briefly borrowing from one of Latour's (1988) examples, before everything articulates successfully into the fact of microbes, what we have is a matter of concern. This is an issue or a concern that (so to speak) gathers an assembly composed by Louis Pasteur and his collaborators, by the social hygienists and their detractors, by yeast and so on. The trajectory of a thing from a matter of concern to a matter of fact involves a process of singularization of the multiplicity and contentiousness of the assembly. This trajectory is of course reversible, as a stabilized fact may again become an issue, thus making visible the presence of the entire assembly that constitutes it. It is important to bear in mind, however, that we are talking of visibility here. Even a fact, a stabilized entity, is always a multiplicity. A multiplicity does not imply many units but rather, in the words of Annemarie Mol (2002) and Marilyn Strathern (2004), more than one but less than many.

Latour (2004a) has argued that, in contrast to a mode of critique that pivots around (what we could call) realist factuality, the point of material-semiotic analyses showing how things are assembled or enacted is not to disavow their reality but rather to show (and, through the analysis, participate in) how they become real in the layering and knotting of multiple concerns; this equally involves how they derealize as their assemblies scatter or turn contentious. Thus, where reasonable politics stands for a politics of hierarchically stratified perspectives on an already existing factual world, material semiotics enables a politics of worlding, that is, a politics concerned with the processes through which a world is being brought into existence. This formulation deactivates the basic premise of reasonable politics - an already existing factual world - and its capacity to adjudicate who and what can be part of the political in terms of their adherence to this particular version of factuality.

As Latour (2007, 813) expresses it:

From now on, politics is something entirely different . . . it is the building of the cosmos in which everyone lives, the progressive composition of the common world. . . . Hence the excellent name Isabelle Stengers has proposed to give to the whole enterprise, that of cosmopolitics. 
In Latour's version of cosmopolitics, the only requirement for things to legitimately be part of the political task of building the common world is that they be an issue, a matter of concern that gathers a public, an assembly. But this rather quick equivalence between cosmopolitics and the progressive composition of the common world seems to rest on Latour's formulation being inspired primarily by scientific controversies; in these cases the multiplicity at stake in a matter of concern that gathers an assembly is already visible and legible, so to speak. Attending more closely to Stengers's version of cosmopolitics, and her insistence on not losing sight of the victims (those with no power to represent themselves or who do not want to take part in the composition of the common world because there is something more important than the proposed issue), Maria Puig de la Bellacasa (2011) has called for the staging of matters of care. At the center of matters of care is the recognition that in deeply stratified worlds, "erased concerns do not just become visible by following the articulate and assembled concerns composing a thing, nor does generating care happen by counting the participants present in an issue" (de la Bellacasa 2011, 94). In this context, feminist notions of critical standpoint become crucial for making visible absent issues. In contrast to deconstructive critique that would wield absences as a weapon to attack the veracity of the assemblage constituting a matter of concern, a critical standpoint foregrounds the absences to foster new attachments and care for heretofore absent participants and concerns. A critical standpoint contributes to cut the shape of an issue otherwise. This is a powerful corrective to Latour's formulation, a corrective that informs my subsequent analysis.

\section{CARING FOR $A T \hat{I} K U$ /CARIBOU: More than One but Less than Many}

Since 2009 I have been involved in a collaborative research project with a group of Innu people from Labrador. The Innu communities are located both in Labrador and Quebec, and are subject to those provincial jurisdictions. The project I describe here started to take shape when I met a group of Labrador Innu elders and hunters from a nonprofit called Tshikapisk. ${ }^{8}$ This group was concerned about the precipitous decline of atîku, which by that time had started to become obvious. As I mentioned before, for many hunters and elders, this population drop signified the deteriorating relationship between the Innu and Kanipinikassikueu, the master of atîku. The concerns of Tshikapisk's members were compounded by the proposal, starting to be advanced by some biologists and an increasing segment of the Labradorian public, that caring for a declining herd of 


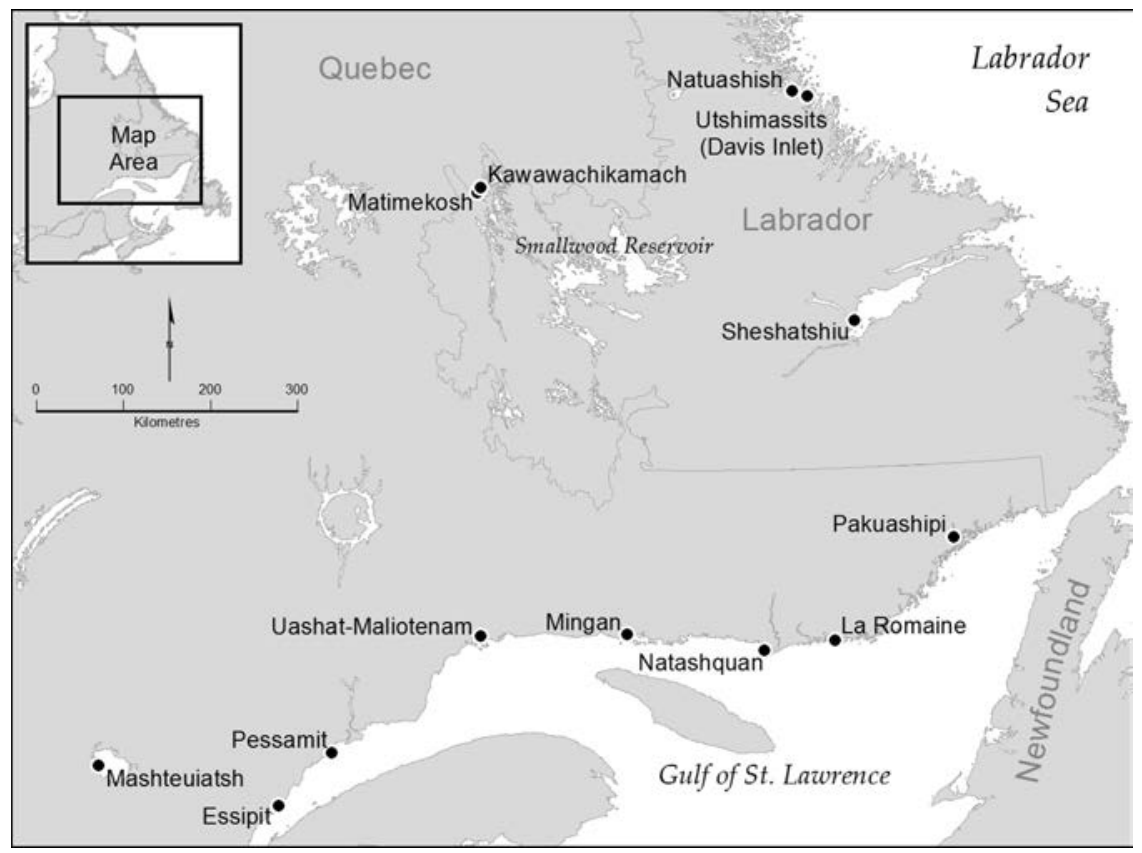

Figure 1. Innu communities in Labrador and Quebec. Map courtesy of Damian Castro.

caribou, in the context of landscape changes, warming temperatures, and resource extraction, demanded that all hunting be halted. ${ }^{9}$ Attending to practices of care that the relationship with Kanipinikassikueu elicits from Innu hunters made evident to us that atîku were quite different from what biologists and Euro-Canadians would call an animal species.

According to an atanukan (stories that narrate the origin of things), an Innu man whose group was starving went to live with the atîku, married the daughter of the herd's leader, turned into atîku himself, and eventually became Kanipinikassikueu. Since then, Kanipinikassikueu persuades atîku to give themselves to the Innu so that the latter can survive. However, this generosity is not guaranteed. As numerous ethnographies have shown, atîku have a will of their own, therefore hunting (nataun) is not centrally about outsmarting animals in order to kill (nipaieu) them, but rather about enticing these fully volitional beings and their leader to be generous with their bodies. This is achieved through practices that show respect and recognition of these altruistic acts. Among these practices are protocols to dispose of the bones of hunted atîku (from which new specimens will regenerate), the injunction not to waste any part of their bodies, and the requirement that meat has to be generously shared among people. Other prescriptions, 
like keeping Kanipinikassikueu in one's thoughts through storytelling, singing, drumming, and celebrating a ceremonial meal (mokoshan) are in place to receive his blessings for general well-being (see Armitage 1992; Henriksen 1973, 2008). Hunting is thus a set of connected caring practices that ensure the ongoing realization of generosity and respect within this collective of human and nonhumans. Yet hunting is also a moment richly indicative of the health of these practices: a decrease in the frequency of atîku giving themselves to hunters is a symptom that Kanipinikassikueu is angry. Reporting on one such circumstance, Georg Henriksen (1977, 7) wrote:

The search for reasons to explain Katipinimitautsh's anger amounts to a selfexamination to find possible failings in [the Innu] spiritual and moral relationship with nature, among themselves, and between themselves and animals. . . . It may be something which is very serious: someone may have breached the rules of sharing, or someone may have been careless when handling the marrow from the caribou long bones.

Most of the elders and hunters whom my colleagues and I engaged in the project understood the declining presence of atîku in this key. They claimed that disrespect for atîku was rampant among younger generations. They spoke of atîku remains being carried away by dogs, of people selling meat, and of a general lack of interest about life on the land among younger people. For most of them the consequences of this were obvious not only in the decline of the herds but also in the epidemic of addiction, suicide, and diabetes that has plagued younger generations of Innu for the past twenty years (see Samson 2003). In a workshop we held in 2010, the elder Ponas Nuke expressed the problem thus: "Without $a t \hat{k} k u$ we are nothing. If we are not in the land, hunting, the day will come when Kanipinikassikueu will not know us, it will ask 'who are you people?' . . . and if we do not have his blessing, things will get worse."

In 2009, the governments of Newfoundland and Quebec agreed to commission a study to evaluate the status of the George River Herd. For this, new radio collars were attached to a number of animals in the herd to allow tracking and counting from helicopters during the summer months. This aerial count, corrected according to established biometric criteria (see Rivest, Couturier, and Crepeau 1998), provided the basis for an estimate of the population. This assessment was then combined with previous studies, as well as other factors known to affect population cycles, to propose a series of measures for the sustainability of the herd that were presented to local stakeholders. These measures hinged on 
the conclusion that hunting was "now significant and cumulative to natural mortality" (Newfoundland and Labrador Wildlife 2010). In other words, caring for the caribou population would require hunting restrictions. In the presentation given to all local stakeholders it was also made clear that, from the government's perspective, conservation efforts held precedence over Aboriginal rights to hunt. Since that meeting, non-Aboriginals began mounting pressure on the government to put a ban on all hunting of the species.

The study and the proposed measures relied on a series of assumptions about caribou that are standard in wildlife biology and management. Thus, the survey was conducted on a specific caribou herd demarcated according to their range and genetic variability. Similarly, the survey relied on the assumption that caribou, driven by instinct, behave in a predictable manner. For example, in the summer, caribou gather in compact groups to protect themselves against blood-sucking insects, so by following the radio-collared animals, surveyors could access the groups and enumerate the animals. In a recent ethnography, Damian Castro (2015, 54-55), one of our project's associates, reports an incident that shows how these assumptions about caribou can stand in stark contrast to the views about atîku held by Innu hunters:

One day, while I was in the Innu Nation office, a very experienced hunter who had been recently charged with illegal hunting came to the office where I was working and told me, "they found a Red Wine [a herd then protected for more than fifteen years] collar close to Lake Kamistastin; see, atîku wants to go there." Lake Kamistastin is located about four hundred kilometers north of Sheshatshiu, very far from the Red Wine Herd range, and right in the migration area of the George River Herd. This information, as he and other Innu argue, shows that the Red Wine woodland herd and the George River migratory herd intermingle. Therefore, there is no point in declaring the hunt illegal on the basis of the assumption upheld by government scientists that the herds are different: for the Innu there is only atîku. Furthermore, the words of this hunter obliquely indicate differences in how the collar information is used. The government uses it to obtain the information the scientists need to learn about caribou behavior, such as their whereabouts, while the Innu use this information to know what atîku wants. In other words, while the government administer the collars to satisfy their will to know, the Innu use it to know the will of atîku. Like human beings, atîku has will. 
The differences between atîku and caribou do not mean there are no connections between them. For instance, the GPS signal sent by the collars to monitor caribou demographics and movements was, until 2010, fed by the Quebec Ministry of the Environment into maps that were available online. Consulting these maps, Innu hunters identified areas where they were likely to come across atîku. This information was extremely important for hunters who wanted to keep their relation with atiku but that have, since the 1970s, found themselves increasingly time-constrained by job obligations in the permanent settlements. Similarly, biologists and wildlife managers had often relied on the support provided by Innu hunters to affix collars and make observations about the caribou. And yet, notwithstanding their mutual entanglements, atîku and caribou remain different. The most obvious way in which this difference manifests is that the former is a nonhuman person that has will, while the latter is an animal driven by instincts. But how to grasp these differences without resorting to notions of different perspectives on a single thing and thus falling into the trap laid by reasonable politics? The conceptual resources of material semiotics discussed in the previous section offer a way. Atîku/caribou is multiple; it is more than one and less than many. Yet the multiplicity at stake here is not exactly the same as that envisioned by Latour or Mol - that is, the idea that a thing is always the stabilized result of a potentially contentious gathering, an assembly or assemblage of actants. In this case, the meaning of multiplicity as being more than one but less than many might be better evoked by the following figure.

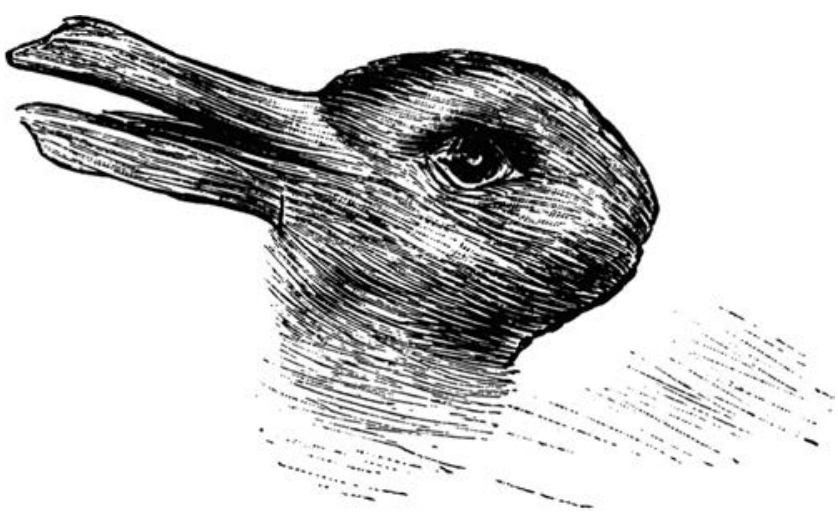

Figure 2. The duck-rabbit illusion.

Here we have a bird looking to the left and a rabbit looking to the right; more than one but less than two. There is a bird and a rabbit, and yet they are 
not two units; and while the traces overlap, there is not just one drawing. If we imagine that the bodies of the bird and the rabbit do not overlap as neatly as their heads, we can grasp the idea that there might be partial co-occurrence of the entities, but the difference is not cancelled. In a similar fashion, the materialsemiotic assemblages from which the more than one less than many atîku/caribou emerges partially co-occur (most evidently in bodily presence) - and at points this co-occurrence may even be mutually enabling (as in the collaring) - but they remain distinct. Atîku emerges from an assemblage that involves atanukan, hunters, the sharing of meat, generosity, a spirit master, and so on; caribou emerges from an assemblage that involves the discipline of biology, wildlife managers, predictive modeling, calculations to balance environmental and economic concerns, and so on. The difficulty in rendering this multiplicity singular, for example through an agreement on how to address declining numbers, should make atîku/caribou a matter of concern. Yet this is not always the case.

\section{ATÎKU/CARIBOU: The Strange Trajectory of an Issue}

As we will see, the (more-than-one-but-less-than-many) atîku/caribou has become an issue in Labrador now. It was not so before, and yet, it was not quite a matter of fact either. The strange trajectory of this issue raises interesting questions about how the specificity of the multiplicity revealed in this case might affect a politics of worlding. To make this trajectory visible, I have to bring into the picture the controversy generated around the proposal for the Lower Churchill Project, a $\$ 6$ billion hydroelectric project and its relation to the complex dynamics of the Labrador Innu comprehensive land claim.

In Canada, comprehensive land claims are geared to trade diffuse Aboriginal title over a territory for clearly defined rights and privileges over more circumscribed areas and resources. Diffuse Aboriginal title over large territories does not deter provincial governments from granting corporations permits to exploit their natural resources. Thus, although carrying the price of extinguishing any right to their entire territory, a land-claim settlement implies legal certainty and a substantial (albeit short-lived) flow of money and jobs from resource development to the communities. Given the trade-offs, comprehensive land claims often produce divisions within communities (see Samson and Cassell 2013). The Labrador Innu land claim is no different. The possibility of settling the land claim became somehow conditional on the Innu accepting the building of the Lower Churchill Project, which was (and continues to be) an extremely contentious issue within communities. Elders and people who retain strong connections with the 
land (of course, including atîku) rejected the project in opposition to a group of leaders inclined to sign a deal.

In spite of these contentions, steps toward the execution of the project continued, including a formal Environmental Impact Assessment (EIA), which is mandated by law and requires a process of consultation with multiple stakeholders. During an EIA, a review panel evaluates the biophysical, social, economic, and cultural effects of the project and the mitigation measures required to offset them. The assessment process generates a report that is submitted to the federal minister of the environment for final approval. The assessment for the Lower Churchill Project started on January 2009 and was rife with controversies between biologists and other wildlife management experts, both governmental and nongovernmental, who disagreed on several points, including the criteria each used to estimate impacts, the selection of indicator species, methods of research, and the like. ${ }^{10}$ Innu concerns entered into the assessment process through a report on land use, commissioned by the Innu Nation and submitted to the review panel, and consultation meetings organized in the communities by the joint review panel. The author of the land-use report stressed that the information provided in it had a crucial limitation: it did "a poor job of conveying the deep meaning and emotion that many Innu have for the land and living entities that reside in the Study Area" (Armitage 2010, 16). Yet something of that meaning and emotion surfaced in the public consultation meeting organized by the review panel. Either directly in English or through an interpreter, several Innu made impassioned presentations about the dam's consequences: "When I think about it, it's like you destroynot only [do] you destroy the land or the animals, you also destroy our livesthe life of the Innu" (JRP 2011b, 148-49). In addition to these overall assessments, Innu presenters had specific concerns about the project's impact on migration patterns and the ability of atîku to travel in a changed landscape. Some participants explicitly wondered about the reactions that powerful nonhumans might have to all this. For example, one of the elders participating in the consultations said:

I don't like the idea of damming the Muskrat Falls. What I know about Muskrat Falls, there's a hole in the falls somewhere. Probably the spirit in the spirit world used that waterfall for a reason, whoever being lives in that hill. Probably the spirit that lives in the mountain probably will destroy the dam itself, somehow. . . . I think that the animal beings who live in that mountain will destroy the dam (JRP 2011b, 71-72). 
Not all Innu gave the same weight to these concerns. A sector of the leadership stressed the benefits of the project and cast the concerns of elders and hunters as a romantic and unrealistic yearning for a way of life no longer possible (JRP 2011b, 103-23). The younger generations thus found themselves having to gauge the concerns of elders and hunters against the promises of jobs and the prospect of ending the legal limbo in which the Innu of Labrador live without a settled land claim. In any case, when the elders' and hunters' concerns were transferred to the report being prepared by the review panel, all mention of nonhumans as something other than animals got translated into culture and addressed as matters of spirituality in the "Heritage and Culture" section (JRP 2011c, 184). In contrast, and with the exception of noting "the moral value" of caribou, the contents of "Traditional Environmental Knowledge" that were amenable to scientific corroboration (e.g., migration patterns, seasonal behaviors, and the like) were included in the section entitled "Impacts to Terrestrial Environment and Wildlife" (JRP 2011c, 114-17). In short, in the report, Innu concerns were split (and implicitly ranked) according to supposedly commonsense criteria that distinguish reliable environmental information from cultural beliefs. After the panel finished the consultations and submitted its report to the federal minister of the environment, the federal government "determined that the expected significant energy, economic, socio-economic and environmental benefits outweigh the 'significant adverse environmental effects' of the Project that had been identified in the Panel Report (Government of Canada 2012, 6).

Environmentalist organizations opposed to the project found in the position of Innu hunters and elders a point of resonance, and thus, in some of their press releases stressed, among other issues, the Aboriginal spiritual values at stake. ${ }^{11}$ Yet this coincidence only went so far. The outrage generated by a protest hunt organized by Quebec Innu is a case in point. These communities organized a hunt among a protected herd in Labrador to make the point that the province of Newfoundland and Labrador should include them and not only the Labrador Innu in the discussions about the Lower Churchill Project. From the Quebec Innu perspective, there was no contradiction between their claim of caring for atîku and hunting them to enforce the notion that, even if the provincial boundaries of the colonial state said otherwise, they were relevant interlocutors in the fate of the territory. The tenor of responses to this action largely resembled that of one reader's comment on the $\mathrm{CBC}$ News website: 
This whole situation just blows my mind. I really can't wrap my head around their mentality. What happened to everything having a spirit and being one with the land? They are raping the land. I bet their ancestors are rolling in their graves. They should be arrested, plain and simple.

Many Euro-Canadians saw the hunt as proof that claims about spiritual connections with atîku were just a ruse that "modernized Aboriginals" were using to extract benefits from the proposed project. In other words, if the spiritual connection with caribou did not translate into what Euro-Canadians would recognize as care, then there was no such connection.

In splitting Innu concerns between acceptable and unacceptable, or between those that could stand alongside science-based knowledge and those that were just "cultural," we can see the work of reasonable politics. But in terms of a politics of worlding, or matters of concern, we can also see that the split makes another distinction. On the one hand, some concerns can compose an issue and therefore aspire to become part of that which might eventually become a matter of fact, a part of the common world. On the other hand, other concerns simply do not constitute an issue. And this of course signals an asymmetry. Being amenable to a form of more or less formalized calculation that rationalizes, among other practices, hunting regulations and massive transformations of the landscape, caribou (and more generally, animals) do affect the composition of atîku. In the most immediate way, this occurs through hunting quotas, the demarcation of protected areas, and the alteration of the herd's migration routes that enforce a recomposition of Innu hunting and meat sharing, practices that partly constitute atîku. In contrast, the presence of atîku has not affected the way in which caribou has been composed, either as a matter of concern during the Lower Churchill controversy or as a quasi-matter of fact, more generally. In other words, Innu concerns for atîku have not been an issue; at least not until recently.

After the environmental review panel conducted its hearings, the Innu communities had a ratification vote on the Tshash Petapen (New Dawn) agreement that the Innu Nation and the provincial government had been negotiating. The agreement contained three parts: a land-claims Agreement-in-Principle (AIP) stipulating the rights that the Innu would retain within a specified territory; economic compensation for the Upper Churchill Project that had been constructed in the late 1960s without regard for Innu rights; and an Impact and Benefits Agreement for the proposed Lower Churchill Project. Overall, the agreement set the general terms under which the Innu land claim would be settled and the construction of 
the Lower Churchill Project could proceed. The overall agreement and its three components, however, had to be ratified separately by the Innu communities. The ratification vote for the overall agreement took place in June 2011. Largely with the support of the younger generations of Innu, the agreement was ratified. This allowed the government of Newfoundland to move on to other crucial aspects of the project, such as financial engineering.

As rumors began to spread at the end of the fall of 2012 that the government of Newfoundland was about to take drastic measures regarding the caribou crisis, the Innu Nation called a community meeting to discuss what they would do in case a ban was imposed. Many of the people who had voted in favor of the Tshash Petapen agreement said that a ban on hunting atîku would be an infringement on the AIP. Therefore, they would now side with the group that had opposed the Lower Churchill Project all along because of its potential effects on atîku and the land more generally. The implications of this shift come into focus when we consider that the AIP still has to be ratified by a vote in the Innu communities and, according to the Tshash Petapen agreement, all three agreements contained in it will become null if any of its components is not ratified by either of the parties. As the results of the community meeting were leaked to the public, the newspaper columnist Michael Johansen (2013) gave voice to a silenced realization: it was yet to be seen whether the Newfoundland government would sacrifice the $\$ 6$ billion hydroelectric project to stop the Innu from hunting. In short, atîku became an inescapable issue.

In contrast to the controversy over the Lower Churchill Project during the EIA process, this time the situation is such that concern for caribou cannot be easily composed without attending to concerns for atîku. However, this is not the typical trajectory of a thing (i.e., caribou) becoming an issue, that is, going from being a matter of fact to being a matter of concern; rather this involves the sudden visibility and unavoidability of participants that were there all along. Yet these participants had no part in the assembly where caribou was staged as a matter of concern with the possibility of being articulated as a matter of fact. This points to the particular problematic that the copresence of different (although asymmetrically and partially connected) assemblages poses to a cosmopolitics oriented to the common world. ${ }^{12}$

\section{CONCLUSION: Common World and Uncommon Worlds}

Although for the most part it has been treated as a discrete entity that can be understood from different perspectives, in Labrador, caribou has never been 
just caribou, a single entity. Yet the multiplicity of the assemblage that can be singularized into a more or less stabilized caribou (for example, in debates about the proper criteria to evaluate the impacts of a development project on herds) is not the same as the one where atîku can be stabilized (for example, in debates about proper protocols to ensure the generosity of the atîku master). What is at stake here is not only ontological multiplicity but also multiple worldings. This raises some fundamental questions. How does a concern in one worlding become an issue in another? What does it take to make an issue across partially connected and stratified worldings? The questions are empirical and also have practical consequences that bear on our roles as analysts and co-composers of matters of concern. De la Bellacasa's (2011) call for matters of care in order to make present absent concerns is crucial, but our case shows that, while necessary, this move is not sufficient to be effective. After all, atîku elicited care (i.e., was made visible as a concern) during the EIA, yet it did not qualify as an issue worthy of attention until it put at risk a multibillion-dollar development project. And even then, one may feel doubtful that atîku had become a matter of concern as conceived by a cosmopolitics oriented to the composition of a common world, that is, as a concern that might aspire to participate in the composition of a matter of fact.

Sometimes different worldings may coexist — enabling each other or without noticing each other-but at other times they interrupt each other. Not being reducible to each other's terms, when and where worldings interrupt each other, the multiplicity at stake might not be amenable to the kind of singularization that Latour's constitution of the common world seems to require. Recall that, for Latour, the composition of the common world is modeled after the trajectory that an assembly might follow from being a matter of concern (a poorly articulated multiplicity of actants on the brink of scattering) to becoming a matter of fact (a gathering of actants that is so well articulated that it becomes stabilized as one singular thing). In this regard, the commentary quoted above that called for police to arrest the Quebec Innu hunters, and the looming threat of arrests under the current ban, prove very telling. In effect, if we take these threats as part of the procedure used to articulate and stabilize caribou as one thing (that is, make it a matter of fact) in spite of the disturbances produced by atîku, one might ponder the consequence of enacting a cosmopolitics as the composition of the common world when the multiplicity at stake is not amenable to singularization.

Latour (2004b, 124) might respond that "of these excluded entities we cannot yet say anything except that they are exteriorized or externalized: an explicit collective decision has been made not to take them into account; they 
are to be viewed as insignificant." So they remain outside the common world being composed. Yet what the atîku/caribou case shows us is that worlding a common world does not always produce just an externality; sometimes it interrupts and destroys other worldings: caring for caribou in certain ways endangers the existence of atîku. In short, rather than something entirely different and insofar as entities that remain outside the common world become insignificant, a cosmopolitics oriented to the common world might end up looking like a reconfigured reasonable politics. This is something that Stengers (2005, 1003) seems aware of: hence, her insistence that the composition of the common world should only proceed in the presence of the victims, not because they must agree, but rather because those who have agreed "have to know that nothing can erase the debt binding their decision to its victim." And yet, while Stengers makes it more difficult and slower than what Latour (2014) seems to seek, the common world "must be composed, nonetheless."

But does it? Can cosmopolitics only offer the slowest possible composition of the common world? Or is another cosmopolitics possible? Inklings of an answer appear in some events that took place shortly before and after the hunting ban was passed.

In response to the problem of the declining presence of atîku as defined by the Innu elders and hunters, our research team had been discussing some interventions. One of them was translating atîku-hunting protocols into policies that could be enforced by the Innu Nation. When rumors of a ban on hunting became acute, members of the research team and staff from the Innu Nation held informal conversations with local personnel from the provincial government's wildlife division. Our intention was to avert the threat of a hunting ban. We argued that, as hunting requires a substantial investment of time and work, if Innu followed proper protocol to treat atîku, there would likely be a reduced number of individuals being hunted. Our pitch to wildlife agents was to name a series of aspects of the situation that were evident to the agents, even if they were reluctant to speak about them openly. First, a ban based on the claim that ceasing hunting would address the caribou crisis was unlikely to garner Innu compliance. Second, the threat of prosecution has never deterred the Innu from hunting, and the actual capacity of the wildlife agents to enforce the ban on the ground was limited. Third, even if wildlife agents could mount an effective plan to enforce the ban, it was doubtful that the upper echelons of the provincial government would give it the green light and risk the Lower Churchill Project. In this context, we argued, collaborating with the Innu Nation in addressing the problem as defined by the 
Innu elders was likely to have better results, even in the terms defined by wildlife managers. Demanding and monitoring that hunters follow proper Innu protocol was likely to generate widespread support in the communities, and consequently fewer animals would be taken. By December 2012, local wildlife agents were considering moving the proposal up the chain of command. But then, in January 2013 and under public pressure, the ban was issued from the ministerial hierarchy. As we had predicted, community members went on hunting in spite of the ban and the provincial government was remiss to enforce it. Wildlife agents monitored the hunt from helicopters, but no hunting-related arrests were made.

The moral of the story, or its relation to another cosmopolitics, is that for a moment we and the wildlife agents achieved what Eduardo Viveiros de Castro (2004, 5) calls "translation as a process of controlled equivocation." Translation as controlled equivocation is premised on the counterintuitive notion that what needs to be kept in the foreground when translating two different terms is, precisely, their difference. This idea contrasts with the common expectation that translation should strive to establish equivalence between two terms through an existing common referent; it also belies the alternative idea that a good translation creates a new common referent. In the former case, translation resonates with the presumption of an already existing factual reality. In the latter case, translation becomes a progressive project to compose a factual reality out of matters of concern and/or care. Yet, in both instances, the assumption is that what connects and makes possible a translation (and a sustained relation) between the terms is a common ground. In our case, rather than striving to discover or enact a common ground, we sought to enable a set of actions that were homonymic: they addressed different things simultaneously. Promoting and enforcing proper nataun protocol (caring for atîku) also meant hunting for fewer animals (caring for caribou); neither the Innu hunters nor the wildlife managers had to subordinate their own practices of caring. In fact, in this translation, caring for caribou and atîku would have reinforced each other. Although the ban prevented this translation coming into future manifestations, while the proposal lasted it constituted a good example of how cosmopolitics might be actively oriented by a vector other than the common world. Here, the uncommon, the difference, in short, the equivocal was a productive vector as well. And I insist, as well, for it is not a matter of either/or but of both/and. There is, here, a fruitful terrain to continue to develop other potentialities of cosmopolitics. 


\begin{abstract}
The concept of cosmopolitics developed by Isabelle Stengers and Bruno Latour keeps open the question of who and what might compose the common world. In this way, cosmopolitics offers a way to avoid the pitfalls of reasonable politics, a politics that, defining in advance that the differences at stake in a disagreement are between perspectives on a single reality, makes it possible to sideline some concerns by deeming them unrealistic and, therefore, unreasonable or irrelevant. Figuring the common world as its possible result, rather than as a starting point, cosmopolitics disrupts the quick recourse to ruling out concerns on the basis of their ostensible lack of reality. And yet, questions remain as to who and what can participate in the composition of the common world. Exploring these questions through ethnographical materials on a conflict around caribou in Labrador, I argue that a cosmopolitics oriented to the common world has important limitations and that another orientation might be possible as well. [ontological politics; cosmopolitics; alterity; science and technology studies; political ontology; Innu; caribou]
\end{abstract}

\title{
NOTES
}

Acknowledgments This paper has been long in the making and I owe thanks to many friends who helped me to think it through, including my constant interlocutors and cothinkers, Arturo Escobar and Marisol de la Cadena; and my collaborators in Nitassinan (Labrador), Damien Benuen, Tony Jenkinson, Richard Nuna, Sebastian Piwas, and Damian Castro. John Law, Juanita Sundberg, and Colin Scott had helpful comments and prodding for earlier versions of the article. The editors of Cultural Anthropology, particularly Cymene Howe, pushed me to improve the article further. Its weaknesses are all mine. The research on which this article is based was funded by the Social Sciences and Humanities Research Council of Canada.

1. The master might also be called Papakashtshihku or Katipinimitautsh (Armitage 1992).

2. As I will show, the disappearance of atîku implies a threat to a whole set of relations and practices that many Innu see fundamental to their existence.

3. Stengers (1997, 75; my translation) says that cosmos is part of "the question of an ecology of practices that brings together our cities, which invented politics, and those other places where the question of closure and transmission has invented other solutions for itself."

4. Among these scholars might be Eduardo Viveiros de Castro (2012), Philippe Descola (2013), Martin Holbraad (2007), and Morten Pedersen (2007).

5. Examples might include the work of Donna Haraway (2008) on companion species, but see Haraway 2015, Tsing 2012, and Barad 2007.

6. Universal Science refers to a variety of knowledge practices that - claiming to follow the experimental sciences' example, but actually distorting the nature of the so-called truths that these produce - claim to know reality "as it is" (see Stengers 2000).

7. In this sense, my call to treat certain conflicts as ontological rather than epistemological (Blaser 2013a, 2013b) is, above all, a call to remain agnostic as to the kinds of differences at stake in a given disagreement. Specific ontological differences are fundamentally a posteriori propositions.

8. The organization was established in 1997 by a group of Innu "concerned with the disruptive consequences that the sudden change from a life based on the country to one based on permanent settlement in villages brought to the Innu" (Tshikapisk Foundation n.d.).

9. The ban on hunting would not be passed until four years later, in 2013. 
10. For instance, the Sierra Club Canada criticized the review panel for failing to assess the environmental effects on the George River Herd (JRP 2011a, 291).

11. See, for instance, http://damsandalternatives.blogspot.ca/2010/12/first-nations-rallyagainst-lower.html.

12. When I refer to "cosmopolitics oriented to the common world," I am indicating that cosmopolitics gains weight as a problematic in relation to the common world. But this does not need to be so, especially in the case of Isabelle Stengers, whose concept of an ecology of practices would not seem refractive to the idea that I develop in this article's conclusion of actively staging divergences as a cosmopolitical move.

\section{REFERENCES}

Armitage, Peter

1992 "Religious Ideology among the Innu of Eastern Quebec and Labrador." Religiologiques 6: 64-110. http://www.religiologiques.uqam.ca/no6/index. html.

2010 “Innu of Labrador Contemporary Land Use Study.” In Labrador-Island Transmission Link Environmental Assessment, prepared by Nalcor Energy, "Socioeconomic Environment: Aboriginal Communities and Land Use Component Study," Appendix A. http://www.env.gov.nl.ca/env/env_assessment/projects/ Y2010/1407/index.html.

Barad, Karen

2007 Meeting the Universe Halfway: Quantum Physics and the Entanglement of Matter and Meaning. Durham, N.C.: Duke University Press.

Blaser, Mario

2009 "The Threat of the Yrmo: The Political Ontology of a Sustainable Hunting Program.” American Anthropologist 111, no. 1: 10-20. http://dx.doi.org/10. $1111 /$ j.1548-1433.2009.01073.x.

2013a “Notes Towards a Political Ontology of 'Environmental' Conflicts." In Contested Ecologies: Dialogues in the South on Nature and Knowledge, edited by Lesley Green, 13-27. Cape Town, South Africa: Human Sciences Research Council Press. http: / / www.hsrcpress.ac.za/product.php?productid=2311.

2013b "Ontological Conflicts and the Stories of Peoples in Spite of Europe: Toward a Conversation on Political Ontology." Current Anthropology 54, no. 5: 547-68. http://dx.doi.org/10.1086/672270.

2014 "Ontology and Indigeneity: On the Political Ontology of Heterogeneous Assemblages." Cultural Geographies 21, no. 1: 49-58. http://dx.doi.org/ $10.1177 / 1474474012462534$.

Carrithers, Michael, Matei Candea, Karen Syke, Martin Holbraad, and Soumhya Venkatesan

2010 "Ontology Is Just Another Word for Culture: Motion Tabled at the 2008 Meeting of the Group for Debates in Anthropological Theory, University of Manchester." Critique of Anthropology 30, no. 2: 152-200. http://dx.doi.org/ 10.1177/0308275X09364070.

Castro, Damian

2015 "Meating the Social: Caribou Hunting and Distribution in Sheshatshiu, Labrador." $\mathrm{PhD}$ dissertation, Memorial University of Newfoundland.

CBC News

2013 “Innu May Hunt Caribou Despite Ban.” January 29. http://www.cbc.ca/news/ canada/newfoundland-labrador/innu-may-hunt-caribou-despite-ban1.1303984 .

Coole, Diana, and Samantha Frost, eds.

2010 New Materialisms: Ontology, Agency, and Politics. Durham, N.C.: Duke University Press.

de la Bellacasa, Maria Puig

2011 "Matters of Care in Technoscience: Assembling Neglected Things." Social Studies of Science 41, no. 1: 85-106. http://dx.doi.org/10.1177/0306312710380301. 
de la Cadena, Marisol

2010 "Indigenous Cosmopolitics in the Andes: Conceptual Reflections beyond 'Politics." Cultural Anthropology 25, no. 2: 334-70. http://dx.doi.org/

Descola, Philippe $10.1111 /$ j. 1548-1360.2010.01061.x.

2013 Beyond Nature and Culture. Chicago: University of Chicago Press.

DiNovelli-Lang, Danielle

2013 "The Return of the Animal: Posthumanism, Indigeneity, and Anthropology." Environment and Society 4, no. 1: 137-56. http://dx.doi.org/10.3167/ares. 2013.040109.

Gad, Christopher, Casper Bruun Jensen, and Brit Ross Winthereik

2015 "Practical Ontology: Worlds in STS and Anthropology." NatureCulture, no. 3: 67-86. http://natureculture.sakura.ne.jp/03-acting-with-non-human-entities.

Government of Canada

2012 "Response to the Report of the Joint Federal-Provincial Review Panel for Nalcor's Lower Churchill Generation Project in Newfoundland and Labrador."

Haraway, Donna http: / / www.ceaa.gc.ca/052/details-eng.cfm?pid=26178.

1988 "Situated Knowledges: The Science Question in Feminism and the Privilege of Partial Perspective.” Feminist Studies 14, no. 3: 575-99. http://dx.doi.org/ $10.2307 / 3178066$.

2008 When Species Meet. Minneapolis: University of Minnesota Press.

2015 “Anthropocene, Capitalocene, Plantationocene, Chthulucene: Making Kin.” Environmental Humanities 6, no. 1: 159-65. http://dx.doi.org/10.1215/ 22011919-3615934.

Henriksen, Georg

1973 Hunters in the Barrens: The Naskapi on the Edge of the White Man's World. St. John's, NL: Institute of Social and Economic Research.

1977 "Land Use and Occupancy among the Naskapi of Davis Inlet." Unpublished report for the Naskapi Montagnais Innu Association,

2008 I Dreamed the Animals: Kaniuekutat. The Life of an Innu Hunter. New York: Berghahn.

Holbraad, Martin

2007 "The Power of Powder: Multiplicity and Motion in the Divinatory Cosmology of Cuban Ifá (or Mana, Again). In Thinking through Things: Theorizing Artifacts Ethnographically, edited by Amiria Henare, Martin Holbraad, and Sari Wastell, 189-225. New York: Routledge.

Holbraad, Martin, Morten Axel Pedersen, and Eduardo Viveiros de Castro

2014 "The Politics of Ontology: Anthropological Positions." In "The Politics of Ontology," Theorizing the Contemporary series edited by Martin Holbraad and Morten Axel Pedersen, Cultural Anthropology website, January 13. https:// Johansen, Michael culanth.org/fieldsights/462-the-politics-of-ontology-anthropological-positions.

2013 “Poking an Innu Bear with a Caribou Stick.” Telegram, February 9. http:// www.thetelegram.com/Opinion/Columns/2013-02-09/article-3173526/

Poking-an-Innu-bear-with-a-caribou-stick/ 1 .

Kirksey, S. Eben, and Stefan Helmreich

2010 “The Emergence of Multispecies Ethnography." Cultural Anthropology 25, no. 4:

Kohn, Eduardo 545-76. http://dx.doi.org/10.1111/j.1548-1360.2010.01069.x.

2015 “Anthropology of Ontologies.” Annual Review of Anthropology 44: 311-27. http://

Latour, Bruno dx.doi.org/10.1146/annurev-anthro-102214-014127.

1988 The Pasteurization of France. Translated by Alan Sheridan and John Law. Cambridge, Mass.: Harvard University Press. Originally published in 1984. 
1999 Pandora's Hope: Essays on the Reality of Science Studies. Cambridge, Mass.: Harvard University Press.

2004a "Whose Cosmos, Which Cosmopolitics? Comments on the Peace Terms of Ulrich Beck." Common Knowledge 10, no. 3: 450-62. http://dx.doi.org/ 10.1215/0961754X-10-3-450.

2004b "Why Has Critique Run Out of Steam? From Matters of Fact to Matters of Concern.” Critical Inquiry 30, no. 2: 225-48. http://dx.doi.org/10.1086/ 421123.

2007 “Turning around Politics: A Note on Gerard de Vries's Paper." Social Studies of Science 37, no. 5: 811-20. http://dx.doi.org/10.1177/0306312707081222.

2014 "Anthropology at the Time of the Anthropocene: A Personal View of What Is to Be Studied." Distinguished lecture at the Annual Meeting of the American Anthropological Association, Washington, DC, December 6.

Law, John

2009 “Actor Network Theory and Material Semiotics." In The New Blackwell Companion to Social Theory, edited by Bryan S. Turner, 141-58. Malden, Mass.: WileyBlackwell.

Lower Churchill Hydroelectric Generation Project Joint Review Panel (JRP)

2011a "Hearing Held at Hotel North Two.” March 17. http://www.ceaa.gc.ca/050/ documents /48784/48784E.pdf.

2011b "Hearing Held at Sheshatshiu Innu School.” March 22. http:/ /www.ceaa.gc.ca/ 050/documents/48945/48945F.pdf.

2011c “Report of the Joint Review Panel.” Minister of the Environment, Government of Canada. http: / / publications.gc.ca/pub?id=9.694768\&sl $=0$.

Mol, Annemarie

2002 The Body Multiple: Ontology in Medical Practice. Durham, N.C.: Duke University Press.

Newfoundland and Labrador Wildlife

2010 “George River Caribou Management.” Presentation. http://www.env.gov.nl. ca/env/wildlife/pdf/GRCH_2010_Consultations.pdf.

Pedersen, Morten

2007 "Talismans of Thought: Shamanist Ontologies and Extended Cognition in Northern Mongolia." In Thinking through Things: Theorizing Artifacts Ethnographically, edited by Amiria Henare, Marten Holbraad, and Sari Wastell, 141-67. New York: Routledge.

Povinelli, Elizabeth A.

2001 "Radical Worlds: The Anthropology of Incommensurability and Inconceivability."Annual Review of Anthropology 30: 319-35. http://dx.doi.org/ 10.1146/annurev.anthro.30.1.319.

2002 The Cunning of Recognition: Indigenous Alterities and the Making of Australian Multiculturalism. Durham, N.C.: Duke University Press.

Rancière, Jacques

2011 "The Thinking of Dissensus: Politics and Aesthetics." In Reading Rancière: Critical

Dissensus, edited by Paul Bowman and Richard Stamp, 1-17. New York:

Continuum. Originally published in 2003.

Rivest, Louis-Paul, Serge Coutourier, and Hélène Crepeau

1998 "Statistical Methods for Estimating Caribour Abundance Using Postcalving Aggregations Detected by Radio Telemetry." Biometrics 54, no. 3: 865-76.

Samson, Colin http://dx.doi.org/10.10.2307/2533841.

2003 A Way of Life that Does Not Exist: Canada and the Extinguishment of the Innu. New York: Verso. 
Samson, Colin, and Elizabeth Cassell

2013 "The Long Reach of Frontier Justice: Canadian Land Claims 'Negotiation' Strategies as Human Rights Violations.” International Journal of Human Rights 17, no. 1: 35-55. http://dx.doi.org/10.1080/13642987.2012.695860.

Stengers, Isabelle

1997 Pour en finir avec la tolérance. Cosmopolitiques, 7. Paris: La Découverte.

2000 The Invention of Modern Science. Translated by Daniel W. Smith. Minneapolis: University of Minnesota Press.

2005 “The Cosmopolitical Proposal.” In Making Things Public: Atmospheres of Democracy, edited by Bruno Latour and Peter Weibel, 994-1003. Cambridge, Mass.: MIT Press.

Strathern, Marilyn

2004 Partial Connection. Updated edition. Walnut Creek, Calif.: Altamira Press. Originally published in 1991 .

Tshikapisk Foundation

n.d. "The Mission of the Tshikapisk Foundation." http://www.tshikapisk.ca.

Tsing, Anna

2012 “Unruly Edges: Mushrooms as Companion Species." Environmental Humanities 1, no. 1: 141-54. http://dx.doi.org/10.1215/22011919-3610012.

Viveiros de Castro, Eduardo

2004 "Perspectival Anthropology and the Method of Controlled Equivocation." Tipiti: Journal of the Society for the Anthropology of Lowland South America 2, no. 1: 3-22. http://digitalcommons.trinity.edu/tipiti/vol2/iss1/1.

2012 Cosmological Perspectivism in Amazonia and Elsewhere: Four Lectures given in the Department of Social Anthropology, University of Cambridge, February-March 1998. Manchester, U.K.: Masterclass Series. 